\title{
Development of Poetry Writing Learning Module Assisted by Religious Songs for Junior High School UNIVA Medan
}

\author{
Hainur Anisa \\ Student Postgraduate Program in \\ Indonesia Language Education \\ Universitas Negeri Medan \\ hainuranisa@gmail.com
}

\author{
Khairil Ansari \\ Lecturer Postgraduate Program in \\ Indonesia Language Education \\ Universitas Negeri Medan \\ Medan, Indonesia
}

\author{
Mutsyuhito Solin \\ Lecturer Postgraduate Program in \\ Indonesia Language Education \\ Universitas Negeri Medan \\ Medan, Indonesia
}

\begin{abstract}
Development of teaching materials is done as an effort to improve learning outcomes and determine the material based on the context of the situation that exists in schools. Paradigms and perceptions that have occurred so far at the Madrasah Tsanawiyah PGA Univa Medan Project namely in developing a teaching material in the form of modules is still minimal, even if there is a form of teaching material used by teachers is still based on textbooks used by schools obtained from the government namely books from the Ministry of Education and Culture. The use of textbooks is one of the tools used by teachers or students as learning resources. Tracing the study of the development of teaching materials in the form of modules to be carried out, researchers conducted a preliminary study consisting of two steps, the first to conduct a field survey and the second to conduct a literature survey. The factor of student interest in learning is still low resulting in the majority of students experiencing difficulty in writing. Learning writing skills take a variety of forms. One of them is writing poetry. Expressing thoughts and feelings in free poetry. Poetry writingis a literary writing skill whose activities describe the contents of the soul, experience, and appreciation by using written language as a tool.
\end{abstract}

Keywords—development, teaching materials, poetry

\section{INTRODUCTION}

Development of teaching materials is done as an effort to improve learning outcomes and determine the material based on the context of the situation that exists in schools. Teachers as educators are tasked with managing and developing learning resources as contained in Article 39 of the National Education System Law No. 20/2013, namely educational staff carrying out administration, management, development, supervision, and technical services to support the education process in education units.

Paradigms and perceptions that have occurred so far at the Madrasah Tsanawiyah PGA Univa Project in Medan that is in developing a teaching material in the form of modules is still minimal, even if there are forms of teaching materials used by teachers are still based on textbooks used by schools obtained from the government namely books from the Ministry of Education and Culture. Another factor that influences the lack of teaching materials in the form of modules developed is from creativity to plan, prepare and make teaching materials in the form of modules. This is also confirmed in Prastowo's book (2015: 14) [1], that the paradigm and general perception inherent among educators is that making teaching material is a difficult job. Resulting in teachers being reluctant to think about finding out how to develop teaching materials. This is supported by data obtained by research entitled "Development of Indonesian Language Learning Modules Assisted by Mind Maps on Writing Materials for Class XI High School / MA Students" that teaching materials used by teachers and students are still based on textbooks, the book is the only source of information for learning.

The use of textbooks is one of the tools used by teachers or students as learning resources. This learning resource is a means used to develop learning material. As a learning resource, textbooks are the main learning resources used in the learning process. In fact, the textbooks students use so far still make them confused in understanding them. Wena emphasized in her book, that the provision of quality textbooks was still lacking, the textbooks used emphasized more on the mere mission of conveying knowledge or facts. Therefore, it is very important to create a teaching material that is easy to understand and interesting for students.

Some previous studies on the study of poetry text learning, obtained data that student learning outcomes in learning poetry texts are still low. These results are contained in research conducted. Indonesian Language and Literature Education Study Program, Padang State University. With the title of the study "Improving Poetry Writing Skills through Image Media Class X.1 Students of State High School 2 Sungai Sungai City" suggests that the low level of learning poetry written by students tends to be informational so that it is less able to arouse emotional readers. Students have not been able to use the right words, so it does not cause a melodious sound that supports the poetic effect of a poem. Furthermore, research conducted by Muhammad Rizqi Romadlon, Sarwiji Suwandi, and Ani Rakhmawati (2016) [2]Masters Program in Indonesian Language Education, FKIP Sebelas Maret University. With the research title "Improving Poetry Writing Skills with Snowball Throwing Model and 
Word Tree Media in Class VII E Students in Negeri 16 Surakarta". Stating that in poetry learning the results are not good and there are those who copy poems that are in books or that are already on student worksheets (LKS). There are also those who write song lyrics without any changes.

The results of the above study note that student interest in learning literature is still low. This is due to the lack of books or teaching materials specifically about learning poetry, which are contained in textbooks that have not been thoroughly discussed, the examples provided are still limited. This is confirmed by the results of research conducted. The findings include 1) student textbooks not yet equipped with Worksheets; 2) assignments and practice questions in textbooks do not yet describe the assessment of problem based learning and project based; 3) the stages of competence achievement in composing text in all basic competencies and types of texts have not shown stages gradually; 4) students have difficulty achieving competence in composing text as a result of learning aspects of skills through project appraisal so that students are less motivated to try it.

\section{METHODS}

This type of research is research and development, namely the development of reading material to write description texts for junior high school grade. According to Sugiyono (2016: 297) [3], research and development methods are research methods used to produce certain products and test the effectiveness of these products. Tegeh et al (2014: 13) [4], states that development research is a research method that is powerful enough to improve learning practices, with the aim of developing new products or improving existing products so that they can be accounted for. This research and development refers to the theory of reading material development proposed by . The steps of development research according to 4D.

This research was conducted at MTs PGA Project Univa Medan located on J1. Sisingamangaraja No. 10 Medan Amplas, North Sumatra. The research will be carried out in June to July 2019. Sugiono (2012: 115) [5], "Population is a generalization consisting of objects / subjects that have certain qualities and characteristics that are determined by researchers to be studied and then conclusions drawn. " The population of this research is all students of class VII MTs PGA Medan Univa Project 2018/2019 academic year. Students are divided into three classes, as shown in table I below:

TABLE I. BREAKDOWN OF THE POPULATION OF GRADE VII STUDENTS OF PTS MTS UNIVA MEDAN 2018/2019 LEARNING YEAR

\begin{tabular}{|c|c|}
\hline No Kiclas & Jomlat Siswa \\
\hline 1. VI:-1 & 19 \\
\hline 2. $1 \mathrm{HI}$ & 19 \\
\hline 3. VIII-3 & 18 \\
\hline Jimiah & 56 \\
\hline
\end{tabular}

The development of this learning module, was developed specifically to study poetry text material. The module that will be developed in this research is writing poetry aided by religious songs guided by the research model and learning system development namely the 4-D model, short for Define, Design, Develop, Desseminate.

The development that will be used to develop learning tools in this study is the 4-D model developed by Thiagarajan (1974). The 4-D model stands for Define, Design, Develop, Desseminate. The development steps in this research are as shown below:

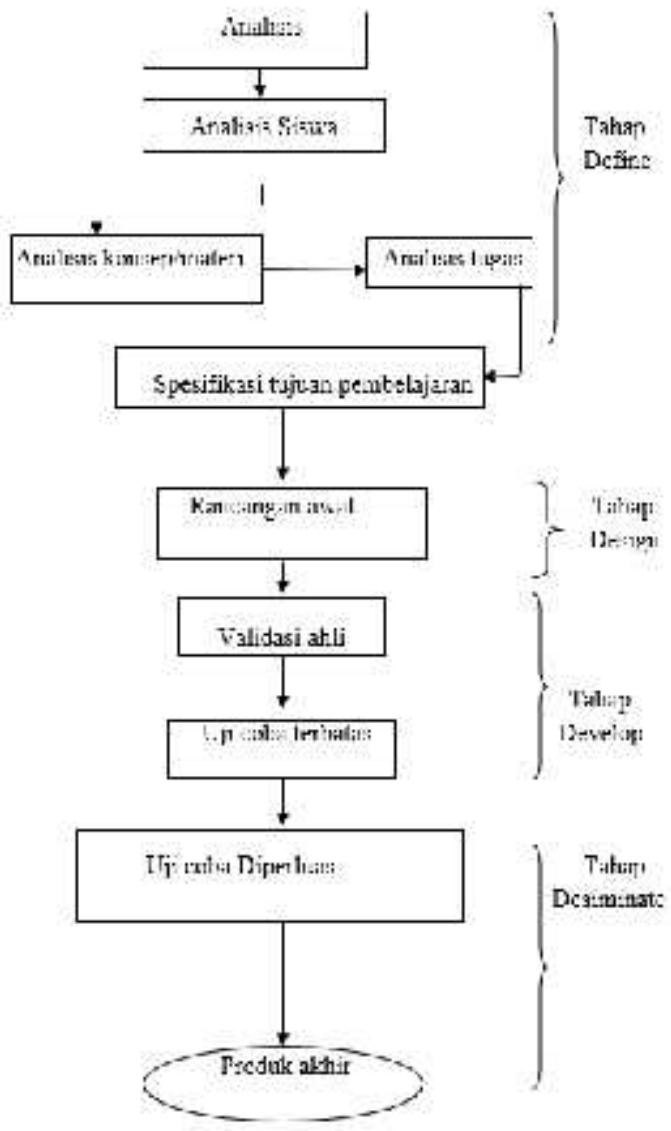

Fig I. Program flow modification for the development of 4-D models in (Muchayar, 2011: 202)

Instruments used in this study to collect data are grouped into 2 kinds, namely:

1. Instrument validation team of experts on learning materials reading description text-based troubleshooting methods.

a. The questionnaire validation sheet of the subject matter material

b. Questionnaire design validation master of the questionnaire

2. Instrument responses of students and teachers on teaching materials

a. Individual trial 3 people 
b. Trial of small group of 9 people

c. Field trials are limited to 32 people

d. Response Indonesian teacher 2 people

The instrument lattice validation sheet by material experts and design experts can be seen in tables II and III below.

TABLE II. ANALYSIS OF THE INSTRUMENTS OF THE ANGKET FEASIBILITY, THE FEASIBILITY OF THE CONTENT, THE FEASIBILITY OF THE LANGUAGE, AND THE FEASIBILITY OF THE PRESENTATION BY THE EXPERTS

\begin{tabular}{|c|c|c|}
\hline No. & Konpouen Indiliawr Penilaian & Bamak: Soil \\
\hline \multicolumn{3}{|c|}{ A. Kelavakan Isi } \\
\hline 1 & Kesesualau uaterl d:nzan K. dun Kd) & 3 \\
\hline$?$ & Kerkinatan maien & 4 \\
\hline 4 & Krontahuran mater & 7 \\
\hline 4 & Merdoronz keir.zintzhuan & 2 \\
\hline \multicolumn{3}{|c|}{ II. Keliygakan Penyajian } \\
\hline 1 & licknik Ponjayjan & 1 \\
\hline 2 & Penkinkung Tenyajian & 6 \\
\hline 3 & Ponyajian Pconbcla aran & 1 \\
\hline 8 & Koherer:i dan Kernetutar. Alur Berpikir & 1 \\
\hline \multicolumn{3}{|c|}{ C. Kelavalian Bahasa } \\
\hline 1. & Lug1s & 3 \\
\hline 2. & Kumuaikalif & 1 \\
\hline 3. & D:shgi: dari Inidtadif & 1 \\
\hline 4. & 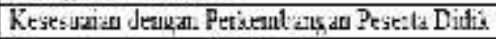 & 2 \\
\hline 5. & Kesesuaian deapar. Kaidai Dahasa & 2 \\
\hline \multicolumn{2}{|r|}{ D. Aspel. Pyailaian tema Cinta Linukumzan } & 7 \\
\hline & Jumlah & 37 \\
\hline
\end{tabular}

Data analysis techniques conducted in this development study is this data collected through expert validation, questionnaire distributed to students. Assessment instruments for validations and individual trials, small groups and limited field groups are created in the likert scale that has been scored as in the table below.

TABLE III. CRITERIA ANSWERS INSTRUMENT VALIDATION ITEM WITH LIKERT SCALE

\begin{tabular}{|l|l|l|}
\hline No. & Answer & Scor \\
\hline 1 & Very Good & 4 \\
\hline 2 & Good & 3 \\
\hline 3 & Not Good & 2 \\
\hline 4 & Poorly & 1 \\
\hline
\end{tabular}

(Sugiyono, 2016: 93)[3]

Then the data is analyzed descriptively quantitative, that is calculated percentage of indicator for each category on instructional material developed.

\section{$\%$ skor $=\frac{\text { number of indicators per category }}{\text { the number of indicators of all categories }} \times 100 \%$}

Based on the calculation of the formula above, the figure is generated in percent. The classification of the score is then changed to classification in the form of percentage (Sugiyono, 2011: 118)[7], then interpreted with qualitative sentences.

\section{RESULT AND DISCUSSION}

Based on the formulation, objectives, results and discussion of teaching materials development research in the form of reading descriptoin text on learning proposed.

Based on the formulation, objectives, results and discussion of teaching materials development research in the form of reading description texton learning proposed.previously mentioned, it can be concluded discussion and research results as follows. At the beginning of the study will spread questionnaire needs analysis to 34 respondents, consisting of 32 students and 2 teachers.

Based on the data needs analysis by students obtained the following conclusions:

1. All teachers and students $(100 \%)$ said they were familiar with the reading description textmedia based on problem solving.

2. All teachers and students $(100 \%)$ stated that they do not use learning-based reading description textinteractive media on learning in the learning process and never use the media.

3. All teachers and students $(100 \%)$ stated needing reading description textinteractive media on learning proposed..

The validation result from the material expert, in the form of scoring score on learning component of reading description textof interactive media on learning, can be known through the assessment done by the material expert from the quality aspect of the learning media which includes the quality of the content feasibility, feasibility of presentation, language feasibility, and feasibility interactive media on learning is rated "excellent" with the percentage of scores for validation scores from material experts is $95.08 \%$.

The validation results of the design experts, in the form of scoring scores on the learning component of reading description textof interactive media on learning, can be known through the appraisal done by the design expert from the quality aspect of the learning media that the aspect of the feasibility of grading is considered "excellent" with the percentage of scores for the validation score from design expert is $86.96 \%$.

The validation result from the material expert, in the form of scoring score on learning component of reading description textof interactive media on learning, can be known through the assessment done by the material expert from the quality aspect of the learning media which includes the quality of the content feasibility, feasibility of presentation, language feasibility, and feasibility based on method problem solving is rated "excellent" with the percentage of scores for validation scores from material experts is $95.08 \%$.

The validation results of the design experts, in the form of scoring scores on the learning component of reading description textof interactive media on learning, can be known through the appraisal done by the design experts from the quality aspect of the learning media that the aspect of the feasibility of the grading is considered "excellent" with the percentage of scores for the validation score from design expert is $86.96 \%$. 
Very good quality individual test $(94,76 \%)$, very good small group test $(97,64 \%)$ and last assessment of field test with excellent quality $(96,20 \%)$, result of effectively test to student studying using learning based interactive is indicated by the results of data processing obtained value " $t$ ", then matched with the table at a significant level of $5 \%=1.66$. This proves that $t$ count $<\mathrm{t}$ table is $1.66<4.07$. Thus, it is concluded that the development of instructional materials in the form of learning medias on reading description text learning is very feasible, easy and effective to used on learning text explanation in high school class XI.

\section{CONCLUSION}

Instrumental in the learning process. The development of teaching materials needs to be done in an effort to improve learning outcomes and establish the material based on the context of the situation in the school. Teaching materials have a very important position in learning, namely as a representation of the teacher's poetry in front of the class. Factors that cause the learning material explanation text conducted by teachers in the classroom is still less interesting and monotonous is the teacher still using conventional materials that are oriented on the results of students, not on the learning process so that students are only given theories of writing and forced to understand the material, while still there are students who have not understood about the material of reading description text and its concept. The accuracy of teachers in choosing, applying and developing teaching materials used in reading description text materials greatly affect the learning process, but in this case the teacher is still not quite right.

Based on the theory, the development of teaching materials in the form of reading description textwith interactive media is needed to support students in improving knowledge in reading description text material. This media is also needed to support the progress of student learning outcomes in reading description text material. The media is also developed with interactive media, this method will serve as the color and characteristic of the media developed and make the media increasingly attract students' attention. The development of this learning media is a programmable development in a systematic sequence and meets the characteristics to support students in learning. The last test subject of two Indonesian subject matter experts, two design instructional experts, three students for individual testing, nine students for small group test and thirtytwo students for field test. Data about the quality of this development product were collected by questionnaire with the result of the research showed that the experimental material was very good $(95,08 \%)$, the test of the excellent category learning to design expert $(86,96 \%)$, the excellent quality individual test $(94,76 \%)$, very good small group test $(97,64 \%)$ and last assessment of field test with very good quality $(96,20 \%)$, result of effectively test to student learning to use problem-based learning media is shown with result of data processing obtained value "t", then matched with table at significant level $5 \%=1.66$. This proves that $\mathrm{t}$ count $<\mathrm{t}$ table is $1.66<4.07$. Thus, it was concluded that the development of teaching materials in the form on learning description text of class VIIjunior high school.

\section{REFERENCES}

[1] Prastowo, Andi. 2015. Panduan Kreatif Membuat Bahan Ajar Inovatif. Jogjakarta: Diva Press.

[2] Faji, Sandya Dwi. 2014. Peningkatan Kemampuan Menulis Puisi Dengan Menggunakan Teknik AkrostikPadaSiswa Kelas VII D SMPNegeri5BanguntapanBantul.Skripsi

[3] Sugiyono. 2016. Metode Penelitian Kuantitatif, Kualitatif dan R\&D. Bandung: Alfabeta.

[4] Tegeh, Made Dkk.2014. Model Penelitian Pengembangan. Yokyakarta: Graha

[5] Sugiyono. 2011. Metode Penelitian Kombinasi (Mixed Methods) Bandung:Alfabeta 